J. Japan. Soc. Hort. Sci. 48(1) : 99-105. 1979.

\title{
Studies on Vegetative Propagation of Tulip
}

\author{
II. Formation and Development of Adventitious Buds \\ in the Excised Bulb Scale Cultured in vitro \\ Yoshio NishiuchI \\ Hokkaido University of Education, Asahikawa 070
}

\begin{abstract}
Summary
In the present work, effects of 2,4-D and kinetin of various concentrations in the medium on adventitious bud formation and its subsequent development in the excised scale of tulip was studied in relation to the morphogenic potential of differently aged bulbs. The concentration and combination of 2,4-D and kinetin with other ingredients in the culture media were modified to find out effective compositions of media that bring about the differentiation of adventitious buds. When excised scales of bulb, cv. 'Apeldoorn', were cultured on Murashige-Skoog's medium, the most suitable combination of auxin combined with kinetin was 1.0-1.4 $\mathrm{mg} / \mathrm{l} 2,4-\mathrm{D}$ for this purpose and that of cytokinin combined with $2,4-\mathrm{D}$ was about $3 \mathrm{mg} / \mathrm{l}$ kinetin.

The initiation of adventitious buds in the scales cultured in vitro was greatly affected by the age of mother bulbs. The cultures failed to initiate bud formation unless cultured explants were taken from the suitably aged bulbs, even when the other conditions were favorable to it. August for 'Apeldoorn' and May for T. hageri were the most suitable time for sampling each bulb scale culture.

Lower concentration of growth substances in the medium were more effective to the subsequent development of newly formed buds when cultured in the light for additional 3 months. As a result, small bulbs were formed eventually at the base of the adventitious bud.
\end{abstract}

\section{Introduction}

It has generally been known that there are many difficulties in propagation of tulip bulbs through tissue culture that is commercially feasible in other bulbous plants such as amaryllis, hyacinth and lily which are capable of producing their bulblets through the scaling of bulbs $(4,9,12)$. Although many attempts to improve the propagation technique for tulip plant have produced unsuccessful results, further development and establishment of more efficient techniques are eagerly expected. As reported in the previous paper (8), vegetative regeneration of this plant is considerably facilitated by tissue culture techniques. It was revealed that adventitious bud formation and its subsequent development were successfully achieved with excised scales of tulip bulbs cultured on the Murashige-Skoog's medium (7) supplemented with auxin and

Received for publication February 2, 1978. cytokinin at proper concentrations.

The present paper gives further information on grow th factors that affect adventitious bud formation and subsequent bulblet proliferation in the excised scales of tulip bulbs. Bulbs of Tulipa gesneriana, cv. 'Apeldoorn', and $T$. hageri were used in this study because they are known to form adventitious buds readily as described in the previous paper (8).

\section{Materials and Methods}

The experiments were carried out with tulip bulbs (Tulipa gesneriana, cv. 'Apeldoorn', and Tulipa hageri) which were supplied from the Experimental Farm of Hokkaido University of Education, 1975 and 1976 harvest. The experimental design for tissue culture was generally the same as described in the previous paper (8). The bulbs were sorted and surface-sterilized with 5\% Antiformin $(0.5 \%$ available chlorine in sodium hypochlo- 
rite solution) for $20 \mathrm{~min}$, followed by 3 wash ing with sterile distilled water and blotted dry. After removal of the basal part of bulbs, discs of the bulb scale, being ca. $100-150 \mathrm{mg}$ in fresh weight (1-1.5 $\mathrm{mm}$ in thickness) and morphologically uniform, were cut with a razor blade. These discs served as initial explants in all subsequent experiments and cultured on a Murashige-Skoog's basic medium (7) which was supplemented with sucrose 20 $\mathrm{g} / l$, casein hydrolysate $2 \mathrm{~g} / l$, glycine $20 \mathrm{mg} / l$, nicotinic acid $5 \mathrm{mg} / l$, pyridoxine hydrochloride $5 \mathrm{mg} / l$, thiamine hydrochloride $1 \mathrm{mg} / l$ and myo-inositol $200 \mathrm{mg} / l$. In addition to these supplements, 2,4-dichlorophenoxyacetic acid(2, 4-D) and kinetin either singly or in combination were incorporated in the basic medium when necessary. The medium was further supplemented with $0.7 \%$ Difco Bacto-ager and adjusted to $\mathrm{pH}$ 5.6. Seventy five milliliters of this medium was dispensed into $300-\mathrm{ml}$ Erlenmeyer flasks capped with double layers of aluminum foil before autoclaving. Five piecs of disces were inoculated into each flask and all cultures were kept under room temperature. Since the bud formation was thought to be under the control of light during the later stages of in vitro scale culture, the propagules were kept under continuous illumination of fluorescent source yielding about $2000 \mathrm{~lx}$ intensity. There were 30 replicates in each treatment.

\section{Results}

1. Regeneration of adventitious bud in the cultured bulb scale.

A morphological observation revealed that the callus proliferation was initiated on the outer periphery along the cut surface of the scales within one month after inoculation when scale pieces were cultured on the basic medium containing 2,4-D and kinetin at appropriate concentrations. The external surface of the callus seemed glistening white and the texture was somewhat compact. After two months, shoot-like outgrowths were scattered over the periphery of these callus tissue, then gradually developed into normal adventitious buds with progress of time. After six months, small bulb-like bodies were formed at the basal part of the adventitious buds. On the
Table 1. Effect of various concentrations of 2,4-D in the medium on the adventitious bud formation of excised 'Apeldoorn' bulb scales cultured in vitro.

\begin{tabular}{cccc}
\hline $\begin{array}{c}\text { Growth regulators } \mathrm{mg} / l \\
\text { Kinetin }\end{array}$ & $\begin{array}{c}\text { Percent bud } \\
\text { initiation }\end{array}$ & $\begin{array}{c}\text { Number of bud } \\
\text { per inoculum }\end{array}$ \\
\hline 0 & 1.0 & 0 & 0 \\
0.3 & 1.0 & 0 & 0 \\
0.8 & 1.0 & 20 & 0.6 \\
1.0 & 1.0 & 33 & 1.0 \\
1.2 & 1.0 & 44 & 1.1 \\
1.4 & 1.0 & 37 & 1.1 \\
0.3 & 2.0 & 0 & 0 \\
0.8 & 2.0 & 27 & 0.9 \\
1.0 & 2.0 & 59 & 1.6 \\
1.2 & 2.0 & 60 & 1.8 \\
1.4 & 2.0 & 52 & 1.8 \\
1.6 & 2.6 & 55 & 1.3 \\
\hline
\end{tabular}

Initial inocula were explanted on August 7, 1975, and data show the results of 15 weeks after inoculation.

basic medium not treated with hormonal supplements, no appreciable response was observed except a slight enlargement of the explant. Data concerning the effect of various concentrations of $2,4-D$ on the adventitious bud formation of scale cultures are shown in Table 1. From an examination of these results, it is readily seen that the culture of scales exhibited the possibility of bud differentiation over a range from 0.8 to 1.6 $\mathrm{mg} / \mathrm{l}$ of $2,4-\mathrm{D}$ and maximum formation in number of buds was achieved at $1.2 \mathrm{mg} / l$ in combination with kinetin. In addition, an increase in kinetin concentration from 1.0 to $2.0 \mathrm{mg} / \mathrm{l}$ augmented the stimulative effect of auxin on bud formation. The results obtained with various concentrations of kinetin in combination with $1.0 \mathrm{mg} / \mathrm{l} 2,4-\mathrm{D}$ are presented in Table 2. From the fact that single application of $2,4-\mathrm{D}$ resulted in no adventitious bud formation unless the culture medium contained appropriate concentrations of kinetin, it is evident that kinetin is essential to the induction of bud formation in vitro and the most effective concentration of kinetin in the medium is around $3.0 \mathrm{mg} / l$.

In the subsequent experiment, bulbs were taken at certain intervals so as to obtain a series of differently aged explants and then cultured immediately to determine their potential of bud formation. In the case of T. hageri, maximum activity of bud formation in vitro was achieved in the samples collected 
Table 2. Effect of various concentrations of kinetin on the adventitious bud formation of excised 'Apeldoorn' scales cultured in vitro.

\begin{tabular}{cccc}
\hline $\begin{array}{c}\text { Grow th regulators } \mathrm{mg} / l \\
\text { Kinetin }\end{array}$ & $2,4-\mathrm{D}$ & $\begin{array}{c}\text { Pescent bud } \\
\text { initiation }\end{array}$ & $\begin{array}{c}\text { Number of bud } \\
\text { per inoculum }\end{array}$ \\
\hline 0 & 1.0 & 0 & 0 \\
0.1 & 1.0 & 0 & 0 \\
0.5 & 1.0 & 7 & 0.2 \\
1.0 & 1.0 & 29 & 0.8 \\
1.3 & 1.0 & 42 & 1.3 \\
1.6 & 1.0 & 37 & 1.3 \\
1.9 & 1.0 & 49 & 1.3 \\
2.2 & 1.0 & 48 & 1.6 \\
2.5 & 1.0 & 46 & 1.6 \\
2.9 & 1.0 & 60 & 1.7 \\
3.2 & 1.0 & 58 & 2.6 \\
3.5 & 1.0 & 31 & 0.8 \\
4.0 & 1.0 & 24 & 0.5 \\
\hline
\end{tabular}

Cultures were started at August 14, 1976, and data show the results of 15 weeks after inoculation.

on May 15 when young bulbs grew vigorously in the field. The activity of bud formation declined gradually until August 7 and failed to recover after it had reached zero level (Fig. 1). In the case of 'Apeldoorn', however, the activity was markedly decreased during the bulb growth period, and thereafter it increased

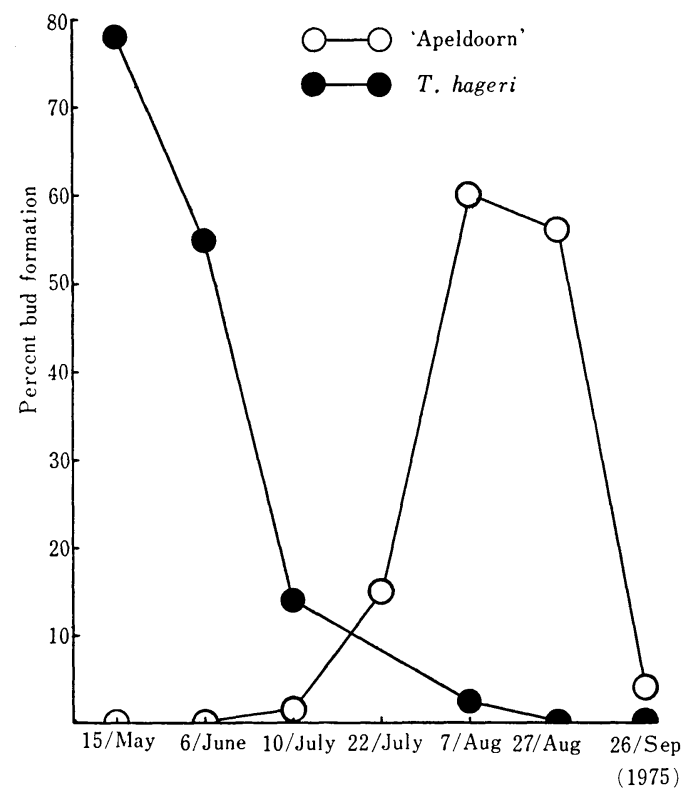

Fig. 1. Time-course changes in bud formation potential due to age difference of bulbs. Culture of 'Apeldoorn' was treated with $1 \mathrm{mg} / \mathrm{l} 2,4-\mathrm{D}$ and $1 \mathrm{mg} / l$ kinetin and that of $T$. hegeri with $5 \mathrm{mg} / l \mathrm{NAA}$ and $1 \mathrm{mg} / l \mathrm{ki}$ netin. Data indicate the results obtained at the end of 15-weeks culture period.

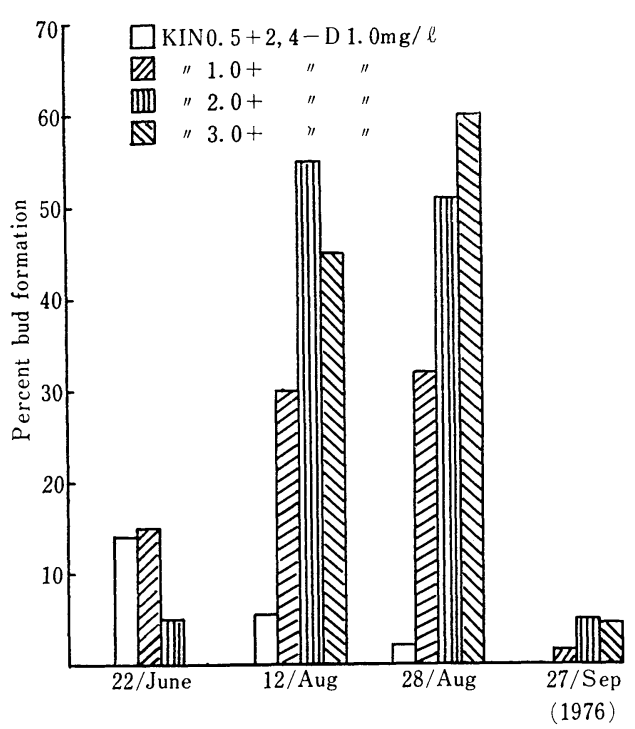

Fig. 2. Effect of kinetin on bud formation of excised scale taken from the differently aged 'Apeldoorn' bulbs. Data indicate the results obtained at the end of 13-weeks culture period.

rapidly and reached a peak on August 7 when bulbs were harvested. The maximum level fell off again to zero on September 26 (Fig. 1). Accompanied by the aging of bulbs, therefore, changes in endogenous growth factors with time seemed to be implicated, to a certain extent, in the regulation of the bud formation in concert with exogenous growth regulators.

The results illustrated in Figure 2 show the change in activity of bud formation in response to the differential supplies of kinetin when initial propagules were taken from differently aged bulbs. Striking differences in bud formation were found between the bulbs of different ages. Although bud formation never occurred in June even when a high concentration of kinetin $(3 \mathrm{mg} / l)$ was applied in combination with $1 \mathrm{mg} / l$ of $2,4-\mathrm{D}$, there was a noticeable improvement as the age of bulbs increased. A similar tendency was found in the cultures on the medium supplemented with less concentration of kinetin $(2 \mathrm{mg} / l)$, though the maximum bud formation took place as early as August 12. It gradually declined until September 27. At the lowest concentration of kinetin $(0.5 \mathrm{mg} / \mathrm{l})$, a slight potential of bud formation was observed in response to kinetin application. This bud formation dec- 
lined as the bulbs aged. It is quite evident, therefore, that increase in kinetin concentration of culture medium is required for successful bud formation in the tissue of cultured scale with advance of bulb age even when the medium is supplemented with appropriate concentrations of 2,4-D. However, the bud formation was suppressed almost completely on September 27 at any kinetin concentrations. This fact suggests that the transition from the developmental to the quiescent stage may be accompanied by a noticeable decline in the bud formation potential of bulbs.

2. Subsequent development of adventitious bud.

In most cultures, adventitious buds continued to elongate without unfolding leaves. As shown in Fig. 3, the subsequent development of buds arising from the callus ( $T$. hageri) was restricted and distorted to become an aborted shoot-like structure when cultured at a high concentration of kinetin $(5 \mathrm{mg} / l)$. Contrary to this, when kinetin level was lowered from $5 \mathrm{mg} / l$ to 2 or $1 \mathrm{mg} / l$, growth of

Table 3. Effect of kinetin on the adventitious bud formation and its subsequent growth of excised $T$. hageri scales cultured in vitro.

\begin{tabular}{ccccc}
\hline $\begin{array}{c}\text { Growth regulators mg/l } \\
\text { Kinetin }\end{array}$ NAA & initiation & $\begin{array}{c}\text { Bud } \\
\text { of } \\
\text { shoot }\end{array}$ & $\begin{array}{c}\text { Production } \\
\text { of } \\
\text { bulbous } \\
\text { thickening }\end{array}$ \\
\hline 0 & 5.0 & - & - & - \\
0.1 & 5.0 & - & - & - \\
1.0 & 5.0 & + & H & + \\
2.0 & 5.0 & + & + & + \\
5.0 & 5.0 & H & + & - \\
\hline
\end{tabular}

Cultures were started at June 7, 1975, and data show the results of 30 weeks after inoculation.

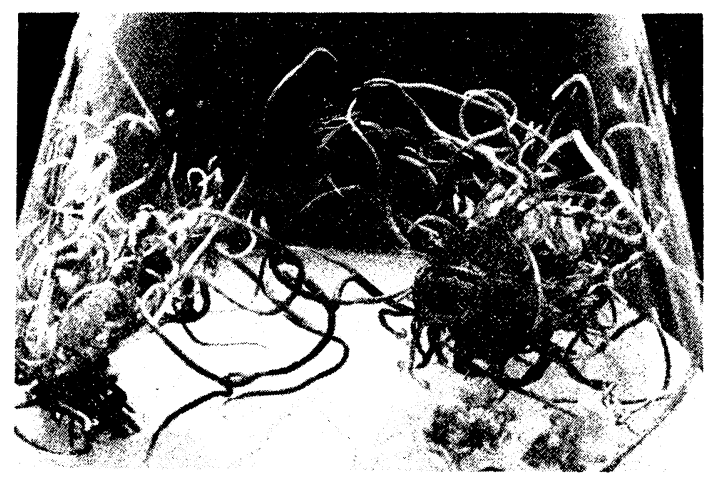

Fig. 3. Abnormal growth of adventitious buds at a high concentration of kinetin $(5 \mathrm{mg} / l)$ in $T$. hageri. formed buds was significantly improved and their growth was kept active during the succeeding 20-25 weeks (Table 3). Meanwhile, the basal part of some elongating buds started to swell, resulting in the formation of bulb-like structures (Fig. 4). In others, the adventitious bud immediately started to thicken, resulting in the formation of compressed stems with fleshy leaves.

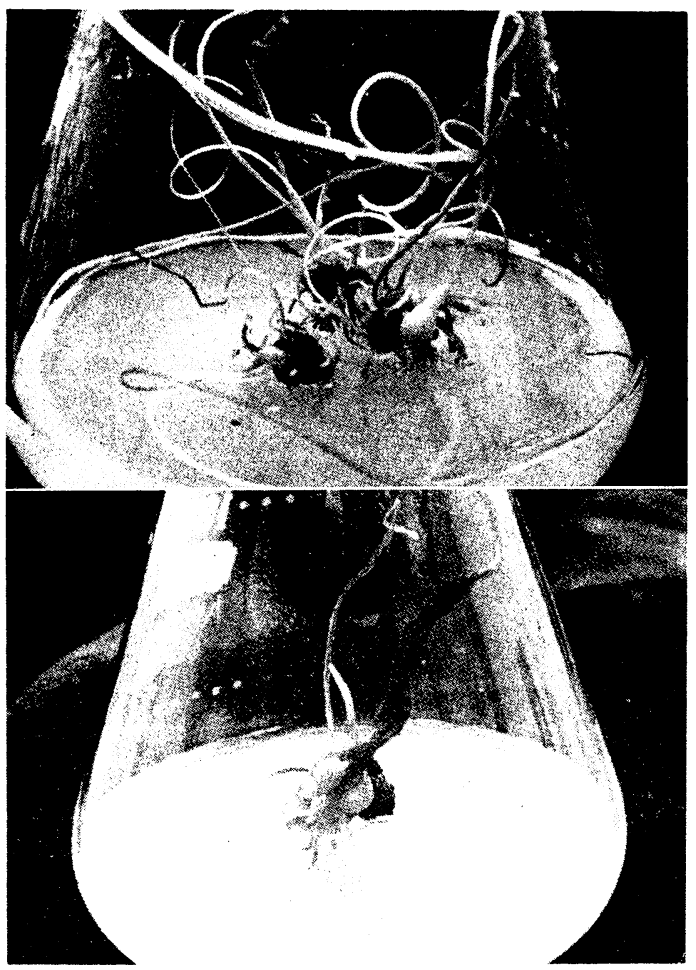

Fig. 4. Bulbous development of a low concentration of kinetin in $T$. hageri.

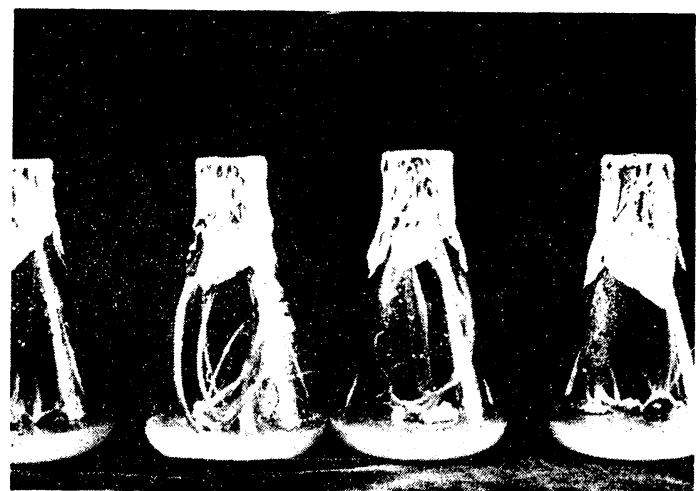

Fig. 5. Buds grown from 'Apeldoorn' scale segments cultured on the medium including $0.3 \mathrm{mg} / l$ NAA and $0.03 \mathrm{mg} / l$ kinetin. 
In the case of 'Apeldoorn' bulbs, excellent and healthy growth of buds was achieved if callus with adventitious buds was transferred to the medium supplemented with $0.3 \mathrm{mg} / l$ NAA and $0.03 \mathrm{mg} / \mathrm{l}$ kinetin (Fig. 5). When the culture was kept under continuous fluorescent light, bulbous thickening was promoted at the base of the elongating buds as the growth progressed (Fig. 6). Some of them produced a dropper-like growth originated

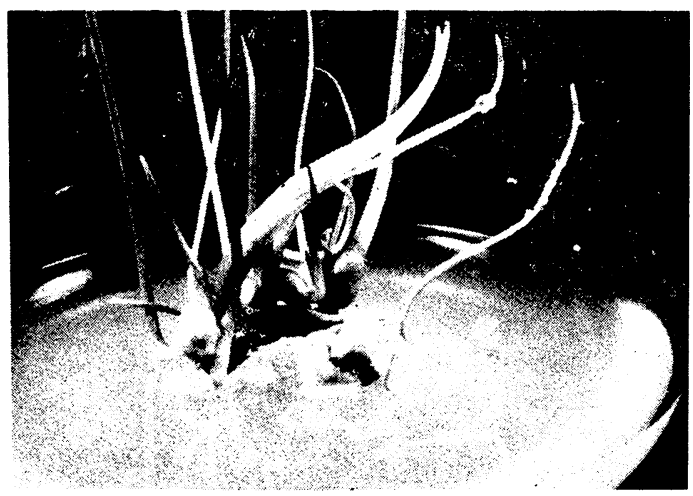

Fig. 6. Bulbous thickening of the adventitious bud in 'Apeldoorn'.
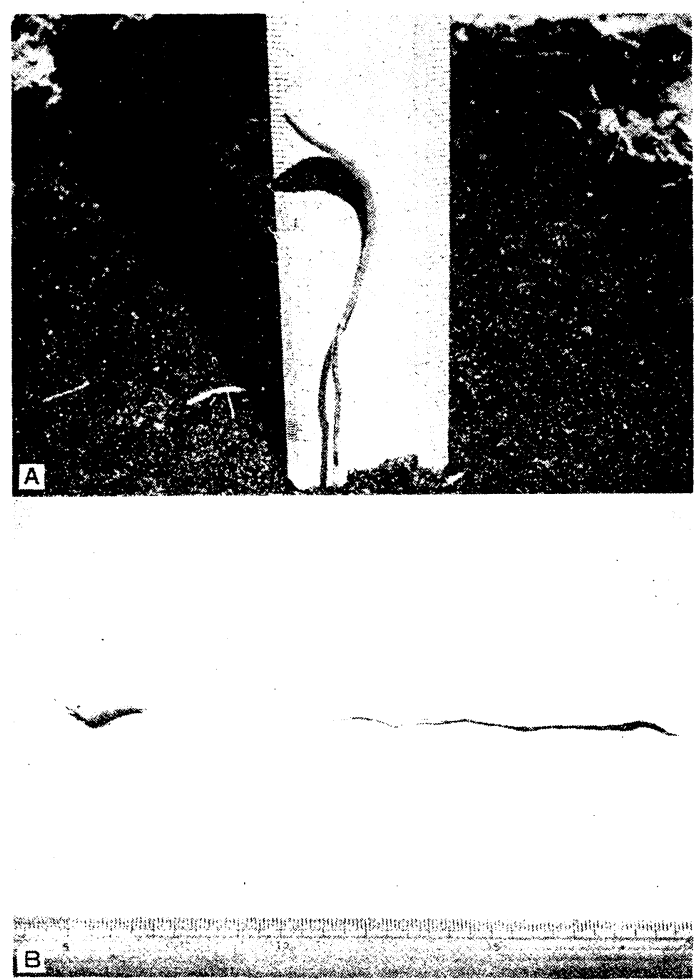

Fig. 7. Shoot growth in the field (A) and a harvested bulb (B) of 'Apeldoorn'. from the base of buds prior to their thickening. Many elongating buds which had acquired bulb-like structures contained no starch grains in their parenchymatous cells and developed necrosis. They soon died without resuming growth. However, a few of the remaining bulblets were grown successfully. Transplanted bulblets in the field finally grew to normal seed bulbs (Fig. 7).

\section{Discussion}

The development of adequately organized bud tissues in the tissue culture depends closely on the growth regulator balance in the medium (5). Since many workers have studied on vegetative propagation of ornamental plants from various standpoints, much evidence has accumulated that cytokinin has a physiological significance as a limiting factor in stimulating the adventitious bud formation. This bud formation is also regulated synergically by auxin action when the following explants are cultured in vitro; leaf cutting of Begonia (6), capitulum of Chrysanthemum cinerariaefolium (11), flower bud of Freesia $(9,10)$ and cormel stem tip of Gladiolus hortulans (13). In the present experiment using excised scales of tulip bulbs, a basic and regulatory mechanism of adventitious bud regeneration appeared to involve the balance between cytokinin and auxin in the culture medium. In particular, the presence of kinetin in the medium was considered to be indispensable to the initiation of adventitious buds. Although the bud formation in the callus was mostly promoted by the application of $3 \mathrm{mg} / l$ kinetin combined with $1 \mathrm{mg} / l$ $2,4-\mathrm{D}$, the conditions favorable for bud formation tended to suppress the subsequent rectilinear growth of the bud. The premature stem thickening and the inhibitory effect of kinetin suggest that kinetin may serve as an inhibitor of the development of elaborately organized bud primordia. Simonsen and Hildebrandt (13) have already found a similar fact that abnormal plantlets originated from the culture of Gladiolus on the medium containing $2 \mathrm{mg}$ kinetin per liter. The severity and frequency of abnormality depended closely on the concentration of kinetin in the culture medium. It is difficult to explain the 
inhibition of bud growth caused by higher concentrations of kinetin in comparison with the promotive effect shown at lower concentrations.

Concerning the effect of light on bud formation, the fact that a dark period of 4 to 6 weeks before the onset of bud formation seems favorable to the development of cultures is compatible with the observation by Pierik and Steegmans $(9,10)$. When these cultures with etiolated buds were exposed to continuous fluorescent light, chlorophylls were formed actively and bud development was stimulated. Light and cytokinin are known to exert some significant effects on the shoot formation $(9,10)$.

There was a discrepancy in bud formation potential in response to the application of growth substances between differently aged bulbs. This may, at least in part, be a reflection of time-course changes in the level of endogenous hormone. In this context, Clark and Heath $(2,3)$ have postulated the existence of a bulbing substance or hormone in the onion plant which is supposed to be IAA. In the tulip bulbs, Aung and Rees (1) also detected an endogenous gibberellin which is expected to exert a beneficial effect on the bulb development. At the moment, however, it is difficult to offer some conclusion on this point. The determination of levels of endogenous growth substances, therefore, is necessary to prove whether both auxin and cytokinin are required for bud formation and also for its subsequent development followed by bulblet proliferation of tulip bulb scales cultured in vitro.

As for the bulbing of tulips, it is generally known that the exposure of bulbs to cool temperatures is prerequisite for stimulating the bulb formation. In the present experiment, only a few bulblets were eventually obtained through in vitro tissue cultures. One of the plausible interpretations of such an unexpected result may be attributed to insufficient chilling treatment.

\section{Acknowledgement}

The auther thanks Professor Hiroshi Myodo and Professor Yozo Okazawa of Hokkaido University for their helpful advice and en- couragement during the course of this study and also for the critical reading of the manuscript.

\section{Literature Cited}

1. Aung, L.H. and A.R. ReEs. 1974. Changes in endogenous gibberllin levels in Tulipa bulblets during ontogeny. J. Exp. Bot. 25(87): $745-751$.

2. Clark, J. E. and O. V. S. Heath. 1959. Auxin and the bulbing of onions. Nature 184: 345-347.

3. — 1962. Studies in the physiology of the onion plant. V. An investigation into the growth substance content of bulbing onions. J. Exp. Bot. $13: 227-249$.

4. FUjiokA, S. 1964. Studies on the bulblet formation in the fractional scale-stem of Amaryllis (in Japanese). J. Japan. Soc. Hort. Sci. 33(2) : 159-170.

5. HALPERIN, W. 1969. Morphogenesis in cell cultures. Ann. Rev. Plant Physiol. 20 : 395-418.

6. HEIDE, O.M. 1965. Interaction of temperature, auxins and kinins in the regulation ability of Begonia leaf cuttings. Physiol. Plant. $18: 891-920$.

7. Murashige, T. and F. Skoog. 1962. A revised medium for rapid growth and bioassays with tobacco tissue cultures. Physiol. Plant. 15 : 473-497.

8. Nishiuchi, Y. and H. MYodo, 1976. Studies on vegetative propagation of tulip. I. Organ formation from excised bulb scales in vitro (in Japanese). J. Japan. Soc. Hort. Sci. 45: $59-64$.

9. PiERiK, R.L.M. and H.H.M. Steegmans. 1975. Effect of auxins, cytokinins, gibberellins, abscisic acid and ethephon on regeneration and growth of bulblets on excised bulb scale segments of hyacinth. Physiol. Plant. 34 : 14-17.

10. — and 1976. Vegetative propagation of Freesia through the isolation of shoots in vitro. Neth. J. Agric. Sci. 24: $274-277$.

11. Roest, S. and G. S. Bokelmann. 1973. Vegetative propagation of Chrysanthemum cinerariaefolium in vitro. Sci. Hort. 1:120122.

12. RовB, S. M. 1957. The culture of excised tissue from bulb scales of Lilium speciosum Thunb. J. Exp. Bot. $8: 348-352$.

13. Simonsen, J. and A.C. Hildebrant. 1976. In vitro growth and differentiation of Gladio- 
lus plants from callus cultures. Can. J. Bot. $\quad 49: 1817-1819$.

$$
\begin{gathered}
\text { チューリップの栄養繁殖に関する研究（第 } 2 \text { 報） } \\
\text { リン片培養に括兴不定芽の形成について }
\end{gathered}
$$

西内義男

(北海道教育大学旭川分校)

\begin{abstract}
摘 要
前回, 十数種のチューリップについて，リン片培養を 行なった結果, 'Apeldoorn'と $T$. hegeri に打いて不 定芽状突起の発生がみられたことを報じたので，本報で はこれらについて，更に不定芽の形成や生育の条件なぞ について検討した.

‘Apeldoorn' の培養りン片に括ける不定芽の形成は, Kinetin の共存下で, $2,4-\mathrm{D} 1.0 \sim 1.4 \mathrm{mg} / l$ を加えると 最も良好であった. また Kinetin 単独添加の場合には, カルスも不定芽も形成されないが，2,4-D の共存下では Kinetin $3.0 \mathrm{mg} / \mathrm{l}$ の添加により不定芽形成は最も促進さ れた。

不定芽の形成は培養時期の違いによって大きな差異が みられ, 'Apeldoorn' では 8 月, T. hegeri では 5 月に 培養すると不定芽が形成され，この他の時期では汪とん ど形成されなかった。

培養リン片より生じた不定芽は NAA 及び Kinetin の低濃度の培地に移植すると良好に生育し，これらを室 内明所で更に $2 \sim 3$ カ月間培養すると, 多くの不定芽に おいて，その基部が球根様に肥大するものと，基部か らドロッパー様に培地に伸長生長するものがみられた. しかし最終的に小球根として残ったものはわずかであっ た.
\end{abstract}

